\title{
In-Vitro Antibacterial Activity of Ruta Chalepensis (Tenadam) and Justicia Shimperiana(Senel) Plants against Some Bacterial Human Pathogens
}

\author{
Habtamu Tedila* Addisu Assefa Velmurugan Shanmugam \\ College of Natural and Computational Science Department of Biology (Stream of Applied Microbiology), \\ Madda Walabu University, PO box 247, Bale Robe, Ethiopia
}

\begin{abstract}
The leave extracts of Ruta chalepensis and Justicia schimperiana were the most powerful medicinal value. The plant extraction followed by ethanol, methanol acetone, diethyl ether and hexane by using disc diffusion and broth dilution methods (MIC) against six human pathogenic bacterial strains (Shigella dysentery, Escherichia coli, Streptococcus aeruginosa, Pseudomonas aeruginosa, Staphylococcus aureus, Salmonella typhi and Klebsiella pneumonia). The methanol extract of $J$. schimperiana showed strong inhibition activity against $S$. dysentery and $E$. coli with a zone size of $14.5 \pm 0.5 \mathrm{~mm}$ and $16 \pm 0.2 \mathrm{~mm}$ and MIC values of $3.12 \mathrm{mg} / \mathrm{ml}$ against $E$. coli and $S$. dysentry. Highly prominent activity was produced by the ethanol extract of $R$. chalepensis with the highest zone of $15 \pm 0.5 \mathrm{~mm}$ diameter observed in $S$. typhi, followed by $S$. aureus $13 \pm 0.11 \mathrm{~mm}$ with the MIC value of $1.56 \mathrm{mg} / \mathrm{ml}$ against $S$. typhi. Four antibiotics were used as standard for the testing of antibacterial activity against six different human pathogens. Among the antibiotics Ciprofloxin showed maximum zone of inhibition ranging from $20-35 \mathrm{~mm}$ followed by Kanamycin, Tetracycline and Chlormphenicol.
\end{abstract}

Keywords: Antibacterial activity, Broth dilution, Disc diffusion, Human pathogens

DOI: $10.7176 / \mathrm{JHMN} / 63-03$

Publication date:June $30^{\text {th }} 2019$

\section{INTRODUCTION}

The discovery and development of antibiotics are among the most powerful and successful achievements of modern science and technology for the control of infectious diseases. The number of multi-drug resistant microbial strains presented (Blair et al., 2015). There is an urgent need to control antimicrobial resistance by improved antibiotic usage and reduction of hospital cross-infection. However, the development of new antibiotics should be continued as they are of primary importance to maintain the effectiveness of antimicrobial treatment (Marchese and Shito, 2001).

The potential for developing antimicrobials from higher plants appears rewarding as it is lead to the development of a phytomedicine to act against microbes; as a result, plants are one of the bedrocks for modern medicine to attain new principles (Evans et al., 2002). Plant based antimicrobials have enormous therapeutic potential as they can serve the purpose without any attributable side effects that are often associated with synthetic antimicrobials. Further continued exploration of plant derived antimicrobials is current needed (Hussain and Gorsi, 2004). Medicinal plants constitute an effective source of both traditional and modern medicines. Herbal medicine has been shown to have genuine utility and about $80 \%$ of rural population depends on it as primary health care (Akinyemi et al., 2005).

In recent years, pharmaceutical companies have spent a lot of time and money in developing natural products extracted from plants, to produce more cost effective remedies that are affordable to the population (Doughari, 2006). The screening of plant extracts and plant products for antimicrobial activity has shown that plants represent a potential source of new anti-infective agents (Salvat et al., 2001; Costa et al., 2008). Numerous experiments have been carried out to screen natural products for antimicrobial property (Ateb and Erdourul, 2003; Nair and Chanda, 2006; Nair et al., 2007; Ndhlala et al., 2009. Many plants have been used because of their antimicrobial traits, which are due to compounds synthesized in the secondary metabolism of the plant (Nascimento et al.,2000).

Ruta chalepensis is strongly scented evergreen sub shrubs $20-60 \mathrm{~cm}$ tall. The leaves are bi pinnate or trip innate. The flowers are yellow, with 4-5 petals, about $1 \mathrm{~cm}$ diameter, and borne in cymes. The fruits of the plant are 4-5 lobed capsules, containing numerous seeds. Traditionally, used as remedy for many inflammatory diseases and as an antispasmodic, as a treatment for menstrual problems, as an abortifacient and as a sedative and for the treatment of rheumatism and mental disorders. In Ethiopia, the leaves are used for myalgia, cold, whooping cough, abdominal pain, anti-emetic, inflammatory diseases, dropsy, neuralgia, rheumatism and menstrual and other bleeding disorders (Figure 1). 


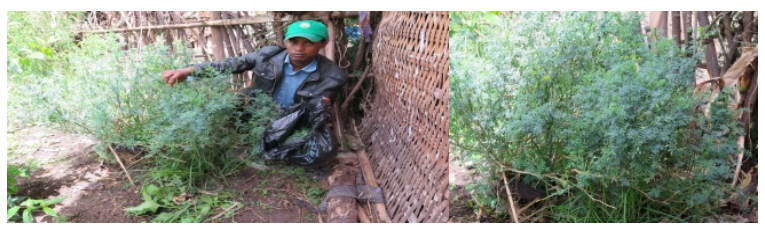

Figure 2A:- Ruta chalepensis Sample collection (My Original photo, 2017).

Justicia schimperiana is belonging to the family acanthaceae which is fast growing on the altitude of $8,000 \mathrm{~m}$ and commonly erect shrub up to $4 \mathrm{~m}$ high. The stem is woody and with internodes; leaves decussate, estipulate, simple, ovate-oblong in outline; inflorescence thyroid, with densely flowered spikes; corolla bilabiate white to creamy white; fruit capsule. J. schimperiana are traditionally used for the treatment of diabetes mellitus, stomachache and burning, constipation and tooth ache and use leafs by mixed with local beer as a remedy against bronchial asthma. Northern Ethiopia the plant alone or in combination with other plants is used for various diseases such as epilepsy, mental illness, eye diseases, jaundice, malaria, leprosy, syphilis, gonorrhea, rabies, measles, relapsing fever, vitiligo, gout and acute febrile illness. In Southwest Ethiopia, it is used for malaria, scabies, where the fresh leaves are crushed and macerated in water and then the affected area is washed with the macerate (Teferi, 2003).

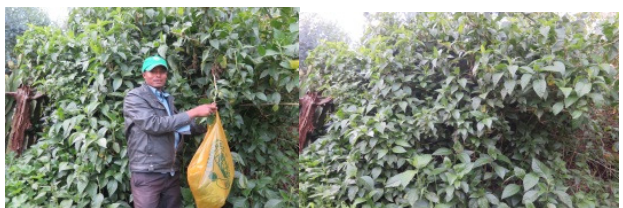

Figure 1B:- Justicia schimperiana sample collection (My Original photo, 2017).

In Ethiopia, plant remedies are still the most important and sometimes the only sources of therapeutics for nearly $80 \%$ of human and more than $90 \%$ in livestock population. Estimated floras of 6500 to 7000 species of higher plants are found in Ethiopia. Out of these 12\% are endemic to the country (Tadeg et al., 2005: Giday et al., 2009). Despite their vital role in catering for the health of human and livestock population, large part of the knowledge of ethno medicinal plants is on the verge of irreversible loss and declining to deterioration due the oral passage of herbal heritage from generation to generation rather than in writings (Mesfin et al., 2009). Environmental degradation, agricultural expansions, cultivation of marginal lands and urbanization are also posing a significant threat to the future wellbeing of human and animal populations that have relied on these resources to combat various ailments for generations (Lulekal et al., 2008: Devi et al., 2009).

\section{Materials and Methods \\ Location of study area}

The study was carried out on some medicinal plants collected from Goba districts of Bale zone, Oromia Regional State, South Eastern Ethiopia. Goba district was located at $445 \mathrm{~km}$ south east of Addis Ababa. The area was situated at $7^{\circ} 00^{\prime} \mathrm{N}$ and $39^{\circ} 58^{\prime}$ E Latitude and longitude respectively. The area has a typical vegetation type of undifferentiated Afromontane forests in Ethiopia and has a mean annual rainfall and temperature of $1218.64 \mathrm{~mm}$ and $10.26^{\circ} \mathrm{C}$, respectively. The economic activities of the local people were primarily based upon mixed farming that involves pastoralism and cultivation of crops such as wheat and barley. 


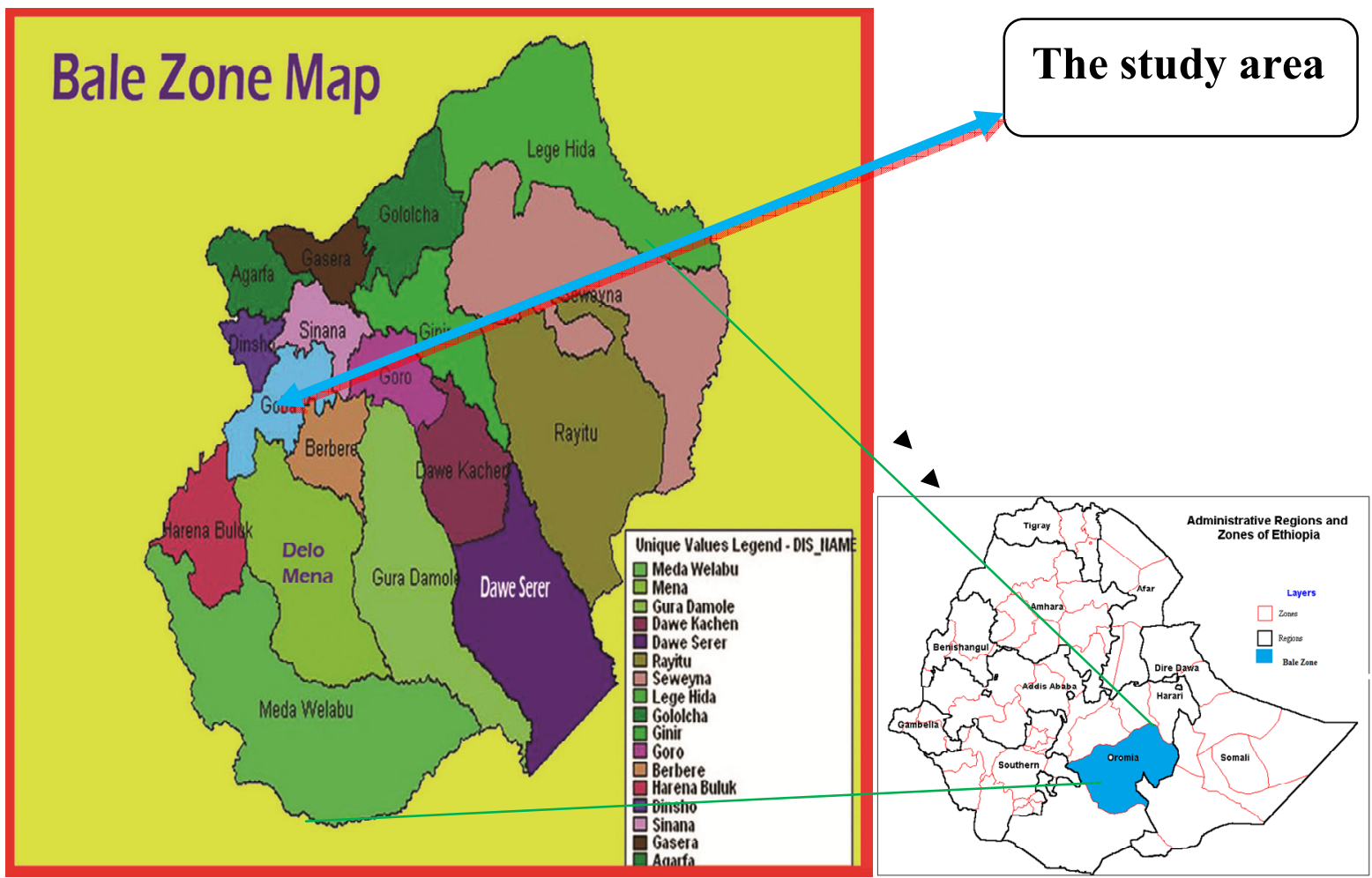

Map of the Study Area

\section{Collection and identification of plant materials}

Two medicinal plants, $R$. chalepensis and J. schimperiana, were collected from Bale Zone, Goba district Oromia region, Ethiopia. The taxonomic position of the plants were identified and authenticated by plant experts from National Herbarium in Addis Ababa University. Leaves from the study plants were taken in a large quantity and repeatedly washed under tap water to remove any debris and were air dried under shade for fifteen days.

\section{Preparation of plant's crude extracts}

The preparation of crude extracts of plants under this study was conducted following the methods used by Hailu Tadeg et al. (2005) using different solvents. Five hundred grams of leaves from each plant was taken for extraction procedure and ground in a mortar and pestle separately under aseptic condition. Twenty grams of each powdered plant material were extracted with apparatus containing $250 \mathrm{ml}$ of Each solvent of ethanol, methanol, diethyl ether, hexane and acetone separately by maceration for $48 \mathrm{~h}$ with frequent agitation on orbital shaker continuously for two days and the resulting liquid was filtered (Whatman No. 3 filter paper, Whatman Ltd., England). Extraction was repeated five times and the filtrates of all portions were combined in one vessel. The organic solvent was removed by evaporation using Rota vapor (BU“CHI Rota-vapor R-205, Switzerland) at no more than $40^{\circ} \mathrm{C}$.

The solvent residue was then placed in an oven at $40 \circ \mathrm{C}$ for about $48 \mathrm{~h}$ to remove the solvent. The resulting dried mass was then powdered, packed into a glass vial until use. Finally, the gram yield of dried residue of each plant extracts were calculated. The concentrated extracts were stored at $4{ }^{\circ} \mathrm{C}$ for the next antimicrobial study. Dried residues were dissolved in $100 \%$ dimethyl sulfoxide (DMSO) to obtain a stock concentration of $100 \mathrm{mg} / \mathrm{ml}$, which was kept at $4{ }^{\circ} \mathrm{C}$ until use.

\section{Preparation of test organisms}

The test organisms including standard pathogens were Escherichia coli, Salmonella typhi, Shigella dysentry, Pseudomonas aerugenosa, Staphylococcus aureus and Klebsiella pneumonia were obtained from Ethiopian Public Health Institute (EPHI), Addis Ababa, Ethiopia. These microorganisms were suspended in nutrient broth and sub cultured into fresh nutrient agar medium and kept at $4^{\circ} \mathrm{C}$ until use. The inoculums preparation were standardized by inoculating bacterial strains from the exponential phase and standardized with $0.5 \mathrm{McF}$ arland turbidity prepared by adding a $0.5 \mathrm{~mL}$ aliquot of $1.175 \% \mathrm{w} / \mathrm{v} \mathrm{BaCl}_{2} .2 \mathrm{H}_{2} \mathrm{O}$, added to $99.5 \mathrm{~mL}$ of $0.18 \mathrm{~mol} / \mathrm{L} \mathrm{H}_{2} \mathrm{SO}_{4}(1 \% \mathrm{v} / \mathrm{v})$.

\section{Antimicrobial Assay}

Antibacterial sensitivity testing using disc diffusion method

For antibiotic susceptibility testing, a stock concentration of $(100 \mathrm{mg} / \mathrm{ml})$ plant crude extracts was prepared in 
DMSO. A circular antibiotic assay disc of $6 \mathrm{~mm}$ diameter was prepared from the Whatman filter paper No.3 and sterilized by autoclaving for $15 \mathrm{~min}$ at $121^{\circ} \mathrm{C}$. The sterile discs were impregnated with $50 \mu 1$ of the reconstituted extract and were dried completely at $37{ }^{\circ} \mathrm{C}$ overnight. A sterile cotton swab was then dipped into a homogenous suspension of test organism with adjusted 0.5 McFarland turbidity standards (Habtamu et al., 2018). The test pathogenic microorganisms were gently spread by streaking onto Muller Hinton Agar (MHA) and then allowed to dry for half an hour. Then the discs were aseptically placed over plates of Muller Hinton Agar (MHA) (Haniyeh et al., 2010). The plates were incubated in an upright position at $37{ }^{\circ} \mathrm{C}$ for 24 hours and the zone of inhibition measured (in mm diameter). Inhibition zones with diameter less than $12 \mathrm{~mm}$ were considered as having low antibacterial activity. Diameters between 12 and $16 \mathrm{~mm}$ was considered moderately active, and those with $>16 \mathrm{~mm}$ were considered highly active (Indu et al., 2006). The test organisms were tested for their sensitivity against the standard antibiotics, Ciprofloxacin $(35 \mu \mathrm{g})$, Chloramphenicol $(30 \mu \mathrm{g})$ Tetracycline $(30 \mu \mathrm{g})$ and Kanamycin $(20 \mu \mathrm{g})$ by the disc diffusion method according to (Habtamu et al., 2019).

\section{Minimum Inhibitory Concentration (MIC) assay methods}

The minimum inhibitory concentration (MIC) was determined by comparing the various concentrations of plant extracts which have different inhibitory effect and selecting the lowest concentration of extract showing inhibition (Agatemor, 2009). The MIC was determined for crude extracts that showed inhibition zone of $\geq 7$ mm diameter and for extract that inhibited the growth of all tested bacteria at concentration of $200 \mathrm{mg} / \mathrm{ml}$. The test was performed by using standard tube dilution (serial dilution) method using nutrient broth as diluents. Accordingly, the plant extract was prepared by double serial dilution from $200 \mathrm{mg} / \mathrm{ml}$ to obtain 1:2, 1:4, 1:8, 1:16, 1:32, and 1:64 in order to get $100,50,25,12.5,6.25,3.125,1.56$ and $0.78 \mathrm{mg} / \mathrm{ml}$ concentration of extract respectively using $50 \%$ DMSO. $1 \mathrm{ml}$ of each extracts was dissolved in sterile test tubes which contained $9 \mathrm{ml}$ of nutrient broth. Then, $0.1 \mathrm{ml}$ of the test organism was inoculated to the each tube. One tube was used as the control (broth + extract). The tubes were incubated at $37{ }^{\circ} \mathrm{C}$ for $24 \mathrm{hrs}$ and the presence of growth was evaluated by comparing the optical density (OD) of each well before and after incubation (Habtamu et al., 2018). When the difference of OD value (after incubationbefore incubation) of the test (broth + extract + organism) was greater than that of the control (broth + extract) at each concentration, it was considered as presence of turbidity or growth of bacteria. The lowest concentration, at which there was no turbidity, was also regarded as MIC value of the extract.

\section{Ethical consideration}

The study was conducted after its approval by the Department of Biology, School of Natural Science, Madda Walabu University. The tests were done in Applied Microbiology Laboratory, Department of Biology using standard good laboratory practices (GLP) to minimize the risk of exposure to human pathogenic bacteria used in the study.

\section{Data Analysis}

Data on mean inhibition zone produced by each plant crude extract and MIC on various bacteria were entered in to Microsoft excels spreadsheet and then exported to SPSS (version 16). The values were given as mean \pm SD.

\section{RESULTS}

\section{Antibacterial activity of the plant extracts}

The crude leave extracts of Ruta chalepensis and Justicia Schimperiana were tested for antibacterial activity on six human bacterial pathogens. The solvents that were used in this study produced an overall yield of plant crude extracts that were ranging from 1.1 to $1.8 \mathrm{gm}$. from different plants (Table.1). The results of study revealed that the tested two medicinal plants Ruta chalepensis and Justicia Schimperiana extracts possess a potential antibacterial activity.

Table 1. The yield of plant crude leave extracts by using different solvents

\begin{tabular}{l|c|c}
\hline Plant species & Extraction type & Yield in grams (Mean) \\
\hline \multirow{3}{*}{ Ruta chalepensis } & Methanol & 1.4 \\
& Ethanol & 1.8 \\
& Diethyl ether & 1.2 \\
& Acetone & 1.3 \\
& Hexane & 1.1 \\
\hline \multirow{3}{*}{ Justicia shimperiana } & Methanol & 1.8 \\
& Ethanol & 1.7 \\
& Diethyl ether & 1.35 \\
& Acetone & 1.18 \\
\hline
\end{tabular}




\section{The antibacterial activity of Ruta chalepensis crude extracts}

The methanolic extract of Ruta chalepensis produced a maximum zone of inhibition of $11.1 \pm 0.55 \mathrm{~mm}$ in diameter against $S$. aureus. The $K$. pneumoniae, $S$. dysentry and $E$. coli exhibited a relatively moderate mean inhibition of $9.5 \pm 0.72 \mathrm{~mm}, 9 \pm 0.4 \mathrm{~mm}$ and $9 \pm 0.3 \mathrm{~mm}$, respectively. The other pathogens showed activity with $P$. aeruginosa $(8.8 \pm 0.26 \mathrm{~mm})$ and $S$. typhi $(7 \pm 0.5 \mathrm{~mm}$.) respectively. The ethanol extract of $R$. chalepensis showed a conspicuous activity against the tested bacterial pathogens. The highest zone of inhibition was observed in $S$. typhi $(15 \pm 0.5 \mathrm{~mm}$ in diameter), followed by $S$. aureus $(13 \pm 0.11 \mathrm{~mm}), P$. aerugenosa $(13 \pm 0.2 \mathrm{~mm})$ and E. coli $(12.5 \pm 0.5 \mathrm{~mm})$ respectively. The least level zone of inhibition was detected against $K$. pneumoniae $(7.9 \pm 0.11 \mathrm{~mm})$.

The acetone crude leave extract of $R$. chalepensis showed a strong zone of inhibition against $K$. pneumoniae $(11.1 \pm 0.28 \mathrm{~mm})$ and a moderate level zone of inhibition against $S$. dysentry, $S$. typhi and $S$. aureus with zone of inhibition of $8.2 \pm 0.3 \mathrm{~mm}, 7.8 \pm 0.26 \mathrm{~mm}, 7.5 \pm 0.5 \mathrm{~mm}$, respectively. The least antibacterial activity was detected against Escherichia coli with a zone size of $5.2 \pm 0.43 \mathrm{~mm}$. Diethyl ether crude leave extract exhibited a moderate antibacterial activity against $S$. dysentry $(7.1 \pm 0.32 \mathrm{~mm})$ and least activity against $K$. pneumoniae $(5.2 \pm 0.2 \mathrm{~mm})$ and $P$. aerugenosa $(51 \pm 0.28 \mathrm{~mm})$. Hexane extract only inhibited $S$. dysentry with a zone of inhibition of $6.3 \pm 0.26$ $\mathrm{mm}$.

Table 2 The Effect of the different extracts of the leaves of Ruta chalepensis against the bacterial test organism using disc diffusion method (Zones of inhibition in mm; Mean \pm SD mm).

\begin{tabular}{|c|c|c|c|c|c|}
\hline \multirow[t]{2}{*}{ Test Organisms } & \multicolumn{5}{|c|}{$\begin{array}{l}\text { Mean Inhibition zone of leaves extract* Ruta chalepensis } \\
(\text { Mean } \pm \text { SD mm) }\end{array}$} \\
\hline & Methanol & Ethanol & Diethyl Ether & Acetone & Hexane \\
\hline Escherichia coli & $9 \pm 0.3$ & $12.5 \pm 0.51$ & - & $5.2 \pm 0.43$ & - \\
\hline Salmonella typhi & $7 \pm 0.5$ & $15 \pm 0.5$ & - & $7.8 \pm 0.26$ & - \\
\hline Shigella dysentry & $9 \pm 0.4$ & $11 \pm 0.1$ & $7.1 \pm 0.32$ & $8.2 \pm 0.3$ & $6.3 \pm 0.26$ \\
\hline Staphylococcus aureus & $11.1 \pm 0.55$ & $13 \pm 0.11$ & - & $7.5 \pm 0.5$ & - \\
\hline Pseudomonas aeruginosa & $8.8 \pm 0.26$ & $13.7 \pm 0.26$ & $5.2 \pm 0.2$ & $6.5 \pm 0.3$ & - \\
\hline Klebsiella pneumonia & $9.5 \pm 0.72$ & $7.9 \pm 0.11$ & $5.1 \pm 0.28$ & $11.1 \pm 0.28$ & - \\
\hline
\end{tabular}

-= implies no inhibition zone detected; * a crude extract of at concemtration of $100 \mathrm{mg} / \mathrm{ml}$ was used for assay The antibacterial activity of Justicia schimperiana crude extracts

The mean zones of inhibition produced by the methanol extract of $J$. schimperiana on $S$. dysentery and $E$. coli were considerably a higher $(14.5 \pm 0.5 \mathrm{~mm}$ and $10.8 \pm 0.2 \mathrm{~mm})$ compared to moderate level zone of inhibition exhibited against $S$. typhi $(8.7 \pm 0.26 \mathrm{~mm})$ and $K$. pneumoniae $(7.7 \pm 0.25 \mathrm{~mm})$. The ethanolic extract of $J$. schimperiana produced the greatest antibacterial activity against all the tested human bacterial pathogens as compared to crude leave extracts by different solvents. With the highest activity produced against $S$. dysentry with the zone size of $16 \pm 0.2 \mathrm{~mm}$, followed by $K$. pneumoniae $(14.8 \pm 0.2 \mathrm{~mm}), S$. typhi $(14.7 \pm 0.3 \mathrm{~mm}), S$. aureus $(13.1 \pm 0.38 \mathrm{~mm})$ and $E$. coli $(12.4 \pm 0.2 \mathrm{~mm})$. Moderate antibacterial activity was exhibited by $P$. aerugenosa $(10.8 \pm 0.28 \mathrm{~mm})$. No least activity observed in the case of ethanolic extract of $J$. schimperiana.

Acetone extract produced maximum zone of inhibition of $8.5 \pm 0.4 \mathrm{~mm}$ against $P$. aerugenosa, $7.3 \pm 0.45 \mathrm{~mm}$ against $S$. dysentery and $7 \pm 0.2 \mathrm{~mm}$ against $E$. coli. K.pneumoniae and $S$. typhi showed an average zone of inhibition of $6 \pm 0.11 \mathrm{~mm}$ and $6.1 \pm 0.36 \mathrm{~mm}$ by acetone crude leave extracts. Diethyl ether crude leave extract also inhibited $E$. coli with a maximum zone size of $11.8 \pm 0.28 \mathrm{~mm}$ and a least activity of $4 \pm 0.15 \mathrm{~mm}$ against $P$. aerugenosa. Whereas hexane crude leaves extract did not exhibit any zone of inhibition against the tested human bacterial pathogens (Table.3)

Table 3 The effect of the different extracts of the leaves of Justicia Schimperiana against the bacterial test organism using disc diffusion method (Zones of inhibition; Mean \pm SD mm)

\begin{tabular}{|l|l|l|l|l|l|}
\hline \multirow{2}{*}{ Test organisms } & \multicolumn{4}{l|}{$\begin{array}{l}\text { Mean zone of inhibition of leaves extract* Justicia Schimperiana } \\
\text { (Mean } \pm \text { SD mm) }\end{array}$} \\
\cline { 2 - 7 } & Methanol & Ethanol & Diethyl Ether & Acetone & Hexane \\
\hline Escherichia coli & $10.8 \pm 0.2$ & $12.4 \pm 0.2$ & $11.8 \pm 0.28$ & $7 \pm 0.2$ & - \\
\hline Salmonella typhi & $8.7 \pm 0.26$ & $14.7 \pm 0.3$ & - & $6.1 \pm 0.36$ & - \\
\hline Shigella dysentery & $14.5 \pm 0.5$ & $16 \pm 0.2$ & - & $7.3 \pm 0.45$ & - \\
\hline Staphylococcus aureus & $6.7 \pm 0.2$ & $13.1 \pm 0.28$ & - & $6 \pm 0.2$ & - \\
\hline Pseudomonas aeruginosa & $6.4 \pm 0.17$ & $10.8 \pm 0.26$ & $4 \pm 0.15$ & $8.5 \pm 0.4$ & - \\
\hline Klebsiella pneumonia & $7.7 \pm 0.25$ & $14.8 \pm 0.2$ & $6 \pm 0.11$ & $6.4 \pm 0.4$ & - \\
\hline
\end{tabular}

NB: - implies no inhibition zone detected; * a crude extract of at concentration of $100 \mathrm{mg} / \mathrm{ml}$ was used for assay.

Inhibitory Zones of test pathogens with Standard Antibiotics (Positive control)

Four different antibiotics such as Ciprofloxin, Tetracycline, Kanamycin and Chloramphenicol were used as 
standard and as positive control for the testing of antibacterial activity of six different human pathogens. The Ciprofloxin showed maximum zone of inhibition ranging from 20-35 against all pathogens; Kanamycin showed average zone of inhibition $20 \mathrm{~mm}$, Tetracycline exhibited ranging from $8-18 \mathrm{~mm}$ and Chloramphenicol showed least inhibition against all test pathogens (Table. 4).

Table 4 The inhibition zone of antibiotics against human pathogens

\begin{tabular}{|c|c|c|c|c|}
\hline \multirow[b]{2}{*}{ Test organisms } & \multicolumn{4}{|c|}{ Zone of inhibition in $\mathrm{mm}$} \\
\hline & Ciprofloxin & Kanamycin & Tetracycline & Chloramphenicol \\
\hline Escherichia coli & 30 & 20 & 15 & 10 \\
\hline Salmonella typhi & 35 & 20 & 15 & 10 \\
\hline Shigella dysentery & 32 & 20 & 13 & 10 \\
\hline Staphylococcus aureus & 31 & 20 & 10 & 5 \\
\hline Pseudomonas aeruginosa & 30 & 15 & 8 & 5 \\
\hline Klebsiella pneumonia & 20 & 15 & 20 & 11 \\
\hline
\end{tabular}
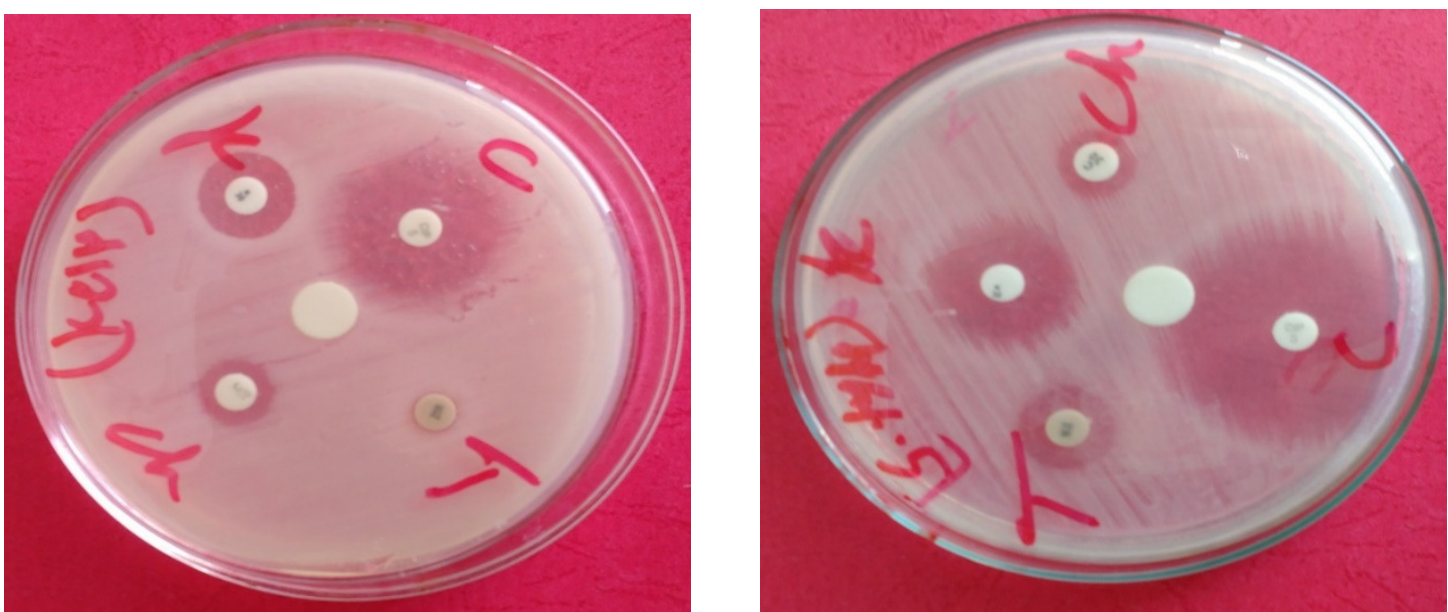

Activity of commercial antibiotics against human pathogens (photo taken after activates).

\section{Minimum Inhibitory Concentration of Plant Extracts (MIC)}

The MIC assay was employed to evaluate the efficacy of the plant crude leave extracts to inhibit the growth of bacterial test organisms. The crude leave extracts of two medicinal plants were subjected to the concentrations ranging from $1.56 \mathrm{mg} / \mathrm{ml}$ to $50 \mathrm{mg} / \mathrm{ml}$. In the antibacterial activity test, five different solvents were used for their in vitro antibacterial test among which only the best three solvents namely methanol, ethanol and acetone were selected for MIC test.

\section{MIC of $R$. chalepensis crude leaves extracts against human pathogenic bacterial organisms}

The methanol extracts of $R$. chalepensis showed inhibitory activity with MIC of $3.12 \mathrm{mg} / \mathrm{ml}$ against $S$. aureus and $P$. aerugenosa, followed by $E$. coli with MIC of $12.5 \mathrm{mg} / \mathrm{ml}$ and $S$. typhi at $25 \mathrm{mg} / \mathrm{ml}$. The MIC of ethanol extract of $R$. chalepensis was $1.56 \mathrm{mg} / \mathrm{ml}$ for $S$. typhi and $3.12 \mathrm{mg} / \mathrm{ml}$ for E. coli and P. aerugenosa respectively. Other pathogenic organisms $S$. dysentry, $S$. aureus and $K$. pneumoniae exhibited higher MICs. On the other hand, the acetone extract had MIC of $25 \mathrm{mg} / \mathrm{ml}$ against all the test pathogenic bacteria (Table 5).

\section{MIC of $J$. schimperiana crude leaves extracts against human pathogenic bacterial organism}

The methanol crude leave extracts of $J$. Schimperiana exhibited a strong MIC activity at $3.12 \mathrm{mg} / \mathrm{ml}$ concentration against $E$. coli and $S$. dysentry followed by $S$. typhi at $12.5 \mathrm{mg} / \mathrm{ml}$ and $K$. pneumoniae at $25 \mathrm{mg} / \mathrm{ml} \mathrm{concentration}$. The MIC of ethanol extract was $3.12 \mathrm{mg} / \mathrm{ml}$ against $S$. dysentry and at $6.25 \mathrm{mg} / \mathrm{ml}$ against $S$. typhi followed by $P$. aerugenosa and $K$. pneumoniae at $12.5 \mathrm{mg} / \mathrm{ml}$ concentration. The Acetone extracts of $J$. Schimperiana showed good inhibition result with MIC of 25 and $50 \mathrm{mg} / \mathrm{ml}$ against the pathogens $S$. dysentry, $S$. aureus and $K$. pneumoniae (Table 6). 
Table 5 MIC of Ruta chalapensis crude leaves extracts against human pathogenic bacterial organism in $\mathrm{mg} / \mathrm{ml}$

\begin{tabular}{|c|c|c|c|c|c|c|c|}
\hline $\begin{array}{l}R . \\
\text { chalapensis }\end{array}$ & $\begin{array}{l}\text { Con } \mathrm{mg} / \\
\mathrm{ml}\end{array}$ & E. coli & S. typhi & S. dysentery & S. aureus & $\begin{array}{l}P . \\
\text { aeruginosa }\end{array}$ & $\begin{array}{l}\text { K. } \\
\text { pneumonia }\end{array}$ \\
\hline \multirow{6}{*}{ Methanol } & 1.56 & - & - & - & - & - & - \\
\hline & 3.12 & - & - & - & $* *$ & $* *$ & - \\
\hline & 6.25 & - & - & - & + & + & - \\
\hline & 12.5 & $* *$ & - & - & + & + & - \\
\hline & 25 & + & $* *$ & - & + & + & $* *$ \\
\hline & 50 & + & + & $* *$ & + & + & + \\
\hline \multirow{6}{*}{ Ethanol } & 1.56 & - & $* *$ & - & - & - & - \\
\hline & 3.12 & $* *$ & + & - & - & $* *$ & - \\
\hline & 6.25 & + & + & $* *$ & & + & - \\
\hline & 12.5 & + & + & + & $* *$ & + & - \\
\hline & 25 & + & + & + & + & + & $* *$ \\
\hline & 50 & + & + & + & + & + & + \\
\hline \multirow{6}{*}{ Acetone } & 1.56 & - & - & - & - & - & - \\
\hline & 3.12 & - & - & - & & - & - \\
\hline & 6.25 & - & - & - & - & - & - \\
\hline & 12.5 & - & - & - & - & - & - \\
\hline & 25 & $* *$ & $* *$ & $* *$ & $* *$ & - & $* *$ \\
\hline & 50 & + & + & + & + & - & + \\
\hline
\end{tabular}

$* *=$ Minimum Inhibitory concentration $+=$ Positive inhibition observed $-=$ No activities (bacterial growth observed)

Table 6 MIC of Justicia Schimperiana crude leaves extracts against human pathogenic bacterial organism in $\mathrm{mg} / \mathrm{ml}$

\begin{tabular}{|c|c|c|c|c|c|c|c|}
\hline $\begin{array}{l}J . \\
\text { schimperiana }\end{array}$ & $\begin{array}{l}\text { Con. } \mathrm{mg} / \\
\mathrm{ml}\end{array}$ & $\begin{array}{l}\text { E. } \\
\text { coli }\end{array}$ & S. typhi & $\begin{array}{l}S . \\
\text { dysentry }\end{array}$ & S. aureus & $\begin{array}{l}P . \\
\text { aeruginosa }\end{array}$ & K.pneumonia \\
\hline \multirow{6}{*}{ Methanol } & 1.56 & - & - & & - & - & - \\
\hline & 3.12 & $* *$ & - & $* *$ & - & - & - \\
\hline & 6.25 & + & - & + & - & - & - \\
\hline & 12.5 & + & $* *$ & + & - & - & - \\
\hline & 25 & + & + & + & - & - & $* *$ \\
\hline & 50 & + & + & + & - & - & + \\
\hline \multirow{6}{*}{ Ethanol } & 1.56 & - & - & - & - & - & - \\
\hline & 3.12 & - & - & $* *$ & - & - & - \\
\hline & 6.25 & - & $* *$ & + & - & - & - \\
\hline & 12.5 & - & + & + & - & $* *$ & $* *$ \\
\hline & 25 & $* *$ & + & + & $* *$ & + & + \\
\hline & 50 & + & + & + & + & + & + \\
\hline \multirow{6}{*}{ Acetone } & 1.56 & - & - & - & - & - & - \\
\hline & 3.12 & - & - & - & - & - & - \\
\hline & 6.25 & - & - & - & - & - & - \\
\hline & 12.5 & - & - & - & - & - & - \\
\hline & 25 & - & - & $* *$ & - & - & - \\
\hline & 50 & - & - & + & $* *$ & $* *$ & $* *$ \\
\hline
\end{tabular}

** = Minimum Inhibitory concentration $+=$ Positive inhibition observed $-=$ No activities (bacterial growth observed)

\section{DISCUSSIONS}

Plants are important source of potentially useful structures for the development of new chemotherapeutic agents. Many reports are available on the antiviral, antibacterial, antifungal, anthelminthic, and anti-inflammatory properties of plants (Palombo and Semple, 2001, Kumarasamy et al., 2002, Stepanovic, et al., 2003, Bylka et al., 2004). Traditional medicine comprises of therapeutic practices that have been in existence, for hundreds of years, before the development and spread of modern medicine and are in use today. In the present study, crude extracts have been eluted from the leaves of two different Plants viz. Justicia schimprena and Ruta chalepensis using five different solvents such as methanol, diethyl ether, ethanol, acetone and hexane. The yield of the extract that was obtained by different solvents considerably differs in two of the medicinal plants (Table 1). 
In these studies, among the solvents used to extract the biologically active substances from two medicinal plants, ethanol and methanol were the best solvents; followed by acetone and least by diethyl ether and hexane (Table 1). So, this displayed that the extraction of medicinal plants with different solvents may show different result which based on the potential of the solvents used to extract the biologically active constituents (George et al., 2010). In the present study, ethanol and methanol crude leaves extracts of J. shimperna and R. chalepensis showed the strongest activity against $E$. coli, $S$. aureus, $S$. typhi, and $S$. dysentry compared with other three solvents and plant based products have been effectively proven for their utilization as source for antimicrobial compounds. The ethanol extract of Ruta chalepensis showed conspicuous activity against the human bacterial pathogens. The highest zone of inhibition was observed in Salmonella typhi measuring around $15 \pm 0.5 \mathrm{~mm}$, followed by.$S$. aureus $(13 \pm 0.11 \mathrm{~mm}), P$. aerugenosa $(13 \pm 0.2 \mathrm{~mm})$ and Escherichia coli $(12.5 \pm 0.5 \mathrm{~mm})$, which strengthens by Tadege et al., 2005 report. Moreover $R$. chalpensis has good inhibition for gram positive bacteria in all the extracts (Ahmed et al., 2010).

The present study showed that S.typhi was the most susceptible test organism for ethanol solvent extract leaves of $R$. chalepensis. The minimum inhibition $(7.9 \pm 0.11 \mathrm{~mm})$ was observed against $K$. pneumonia by ethanol extraction. Similar extract was reported to have activity against the pathogenic $S$. mutants (Tadege et al., 2005). Diethyl ether extract exhibited moderate antibacterial activity of $7.1 \pm 0.32 \mathrm{~mm}$ against $S$. $d y$ sentery and least activity against $K$. pneumoniae $(5.2 \pm 0.2 \mathrm{~mm})$, and $P$. aerugenosa $(5.1 \pm 0.28 \mathrm{~mm})$. In the present study, the MIC of ethanol extract of $R$. chalepensis was $1.56 \mathrm{mg} / \mathrm{ml}$ against $S$. typhi and $3.12 \mathrm{mg} / \mathrm{ml}$ against Escherichia coli and $P$. aerugenosa. The result of the study clearly indicates that methanol and ethanol extracts are good in inhibiting the bacteria tested. Methanol extract of $J$. schimperiana on $S$. dysentry and $E$. coli was highly significant with a zone size of $14.5 \pm 0.5 \mathrm{~mm}$ and $10.8 \pm 0.2 \mathrm{~mm}$ which is in agreement with Pavithra et al (2011) who reported that the methanol extracts of Mollugo cerviana inhibited the growth of $S$. aureus and E. coli with zones of $7.33 \pm 0.57$ to $11 \pm 1$, while chloroform extracts were ineffective against these bacterial strains.

The ethanolic extract of $J$. schiperiana was found to be the best which produced the maximum antibacterial activity against all the tested pathogens with the highest activity produced against $S$. dysentery with the zone size of $16 \pm 0.2 \mathrm{~mm}$, followed by $K$. pneumoniae $14.8 \pm 0.2 \mathrm{~mm}, S$. typhi $14.7 \pm 0.3 \mathrm{~mm}, S$. aureus $13.1 \pm 0.38$ whereas Acetone extract produced a maximum zone of inhibition around $8.5 \pm 0.4 \mathrm{~mm}$ against $P$. aerugenosa, $7.3 \pm 0.45 \mathrm{~mm}$ against $S$. dysentery and $7 \pm 0.2 \mathrm{~mm}$ against $E$. coli. Similar results have been reported by previous findings (Mahesh and Satish, 2008; Rajendran and Ramakrishnan, 2009; Sundaram et al., 2011. MIC activity at $3.12 \mathrm{mg} / \mathrm{ml}$ concentration of methanol extract of $J$. schimprene observed against $E$. coli and $S$. dysentry followed by $S$. typhi. The differences between the antibacterial activity of the two medicinal plant species show variations not only among different chemical extraction, but also among different species of plants; and in inherent resistance of the tested bacteria species (Nayan et al., 2011).

\section{CONCLUSION}

From the above results it could be concluded that the crude leave extracts of the two plants especially the ethanol and methanol revealed that they have higher potential to produce broad spectral antibacterial activity with minimal concentration against a wide range of human pathogens. The extracts were good in inhibiting Escherichia coli, Salmonella typhi, Shigella dysentery, Pseudomonas aerugenosa and in some instances Klebssiella pneumoniae. The results of this study provide an insight into the anti-microbial properties of the extracts of Ruta chalepensis and Justicia schimperiana. As well, it created an opportunity for phytoscreening of bioactive extracts for initial fractionation and further studies of these two medicinal plants in the antibacterial assays. This in vitro study demonstrated that these two folklore medicinal plants have good potential. This study gives an indication of the efficacy of the plants obtained from the traditional healersb and form a basis for further studies of the potent plants so as to isolate the bioactive compounds responsible for the antimicrobial activity.

\section{Competing Interests}

The authors declare that they have no competing interests.

\section{Acknowledgments}

The authors would like to thank the Madda Walabu University for providing the facilities to work and Ethiopian Public Health Institute (EPHI) for support standard pathogen isolation and National Herbarium in Addis Ababa University for taxonomic plants identified and authenticated.

\section{REFERENCES}

Agatemor, C (2009). Antimicrobial activity of aqueous and ethanol extracts of nine Nigerian spices against four food borne bacteria. Elec J Environ Agric food chem., 8(3): 195-200.

Ahmed, AE, Fathalla, MH, Salah, AG, Ayman, AN, Mansour, IS, Essam, A (2010). Antihepatotoxic effect of Marrubium vulgare and Withania somnifera extracts on carbon tetrachloride- induced hepatotoxicity in rats. 


\section{J. B. Clin. Pharm., 1: 247-254.}

Akinyemi, KO, Oladapo, O, Okwara, CE, Ibe, C, and Fasure, KA (2005). Screening of crude extracts of six medicinal plants used in South-West Nigerian unorthodox medicine for anti-methicillin resistant Staphylococcus aureus activity. BMC Complementary and Alternative Medicine 5: 6-13.

Ateb, DA, and Erdourul, T (2003). Antimicrobial activities of various medicinal and commercial plant extracts. Turkish Journal of Biology. 27: 157-162

Blair JMA, Webber MA, Baylay (2015). Molecular mechanisms of antibiotic resistance. Nat Rev Micro. 13:4251. [PubMed] [Google Scholar]

Bylka, W, M Szaufer-Hajdrych, I. Matalawskan and O.Goslinka (2004). Antimicrobial activity of isocytisoside and extracts of Aquilegia vulgaris L. Lett. Appl. Microbiol., 39: 93-97.

Costa , ES, Hiruma-Lima , CA, Lima, EO, Sucupira, GC, Bertolin, AO, Lolis, SF, Andrade, FDP, Vilegas, W and Souza-Brito ,ARM (2008). Antimicrobial activity of some medicinal plants of the Cerrado, Brazil. Phytotherapy Research. 22: 705-707.

Devi, K, Karthikai, GD,Thirumaran, G, Arumugam, R, and Anantharaman, P (2009).Antibacterial activity of selected medicinal plants from Parangipettai coastal regions; Southeast coast of India. World App Sci J. 7(9):1212-1215.

Doughari, JH (2006). Antimicrobial activity of Tamarindus indica Linn. Tropical Journal of Pharmaceutical Research 5: 597-603.

Evans, CE, Banso , A and Samuel,OA (2002). Efficacy of some nupe medicinal plants against Salmonella typhi: an in vitro study. Journal of Ethnopharmacology 80: 21-24.

George, FOA, Ephraim, RN, Obasa, SO, and Bankole, MO (2010). Antimicrobial properties of some plant extracts on organisms associated with fish spoilage. University of Agriculture, Abeokuta (UNAAB) Nigeria.

Giday, M, Asfaw, Z, and Woldu, Z (2009). Medicinal plants of the Meinit ethnic group of Ethiopia: An ethnobotanical study. J. Ethnopharmacol. 124: 513-521.

Habtamu T, Addisu A, Ayalew S, (2018). In-vitro antibacterial activity of Dodonaea angustifolia and Withania somnifera plants against some bacterial human pathogens. J. natural Sciences research 8(15), 2018.

Hailu Tadeg, Endris Mohammed, Kaleab Asres, Tsige Gebre-Mariam (2005). Antimicrobial activities of some selected traditional Ethiopian medicinal plants used in the treatment of skin disorders. Journal of Ethnopharmacology 100: 168-175

Haniyeh ,K, Seyyed, M, Seyyed, N and Hussein, M (2010). Preliminary study on the antibacterial activity of some medicinal plants of Khuzestan (Iran). Asian Pacific Journal of Tropical Medicine 3(3) : 180-184.

Hussain, MA, and Gorsi, MS (2004). Antimicrobial activity of Nerium oleander Linn. Asian Journal of Plant Sciences 3:177-180.

Indu, MN, Hatha, AA M., Abirosh, C, Harsha, U, and Vivekanandan G (2006). Antimicrobial Activity of Some of the South-Indian Spices against Serotypes of Escherichia Coli, Salmonella, Listeria

Kumaraswamy, Y, PJ, Cox, M, Jaspars, L,Naharand,S. and Sarker,D (2002). Screening seeds of Scottish plants for antibacterial activity. J. Ethnopharmacol., 83:73-77.

Lulekal, E, Kelbessa, E, Bekele, T and Yineger, H (2008). An ethnobotanical study of medicinal plants in Mana Angetu District, southeastern Ethiopia. J Ethnobiol Ethnomed. 4:1-10.

Mahesh, B and Satish,S (2008). "Antimicrobial Activity of Some Important Medicinal Plant against Plant and Human Pathogens." World. J. Agri. Sci. 4: 839-843.

Marchese, A. and Shito, GC (2001). Resistance patterns of lower respiratory tract pathogens in Europe. International Journal of Antimicrobial Agents 16: 25-29.

Mesfin, F, Demissew, S and Teklehaymanot, T (2009). An ethnobotanical study of medicinal plants in Wona Woreda, SNNPR, Ethiopia. J Ethnobiol Ethnomed. 5:28.

Nair, R and Chanda, S (2006). Activity of some medicinal plants against certain pathogenic bacterial strains. Indian Journal of Pharmacology 38: 142-144.

Nair, R, Vaghasiya, Y and Chanda, S (2007).Antibacterial potency of selected Indian medicinal plants. International Journal of Green Pharmacy. 1: 37 -44.

Nascimento, G, Locatelli, P, Freitas, C and Silva, G (2000): Antibacterial Activity of Plant Extracts and Phytochemicals on Antibiotic resistant Bacteria. Brazilian Journal of Microbiology 31:247-256.

Nayan, RB, Shukla,VJ, Acharya, RN, Rajani, DP (2011). Antimicrobial screening of seed extracts of Cassia fistula linn. International Journal of Advances in Pharmacy and Nanotechnology., 1-8.

Ndhlala, AR, Stafford, GI, Finnie, JF and Van Staden, J (2009). In vitro pharmacological effects of manufactured herbal concoctions used in KwaZulu-Natal South Africa. Journal of Ethnopharmacology. 122: 117-122.

Palombo, EA and Sampled, SJ (2001). Antibacterial activity of traditional medicinal plants. J. Ethnopharmacol., 77: $151-157$.

Pavithra, PS, Janani, VS, Charumathi, KH, Indumathy, R, Potala, S, and Verma, RS (2011). Antibacterial activity of plants used in Indian herbal medicine. Int. J. Green Pharm. 4(1):22-28. 
Rajendran, NK and Ramakrishnan J (2009). In vitro evaluation of antimicrobial activity of crude extracts of medicinal plants against multi drug resistant pathogens. Biyoloji Bilimleri Araptyrma Dergisi, 2: 97-101.

Salvat, A, Antonnacci, L, Fortunato, RH, Suarez, EY and Godoy, HM (2001). Screening of some plants from Northern Argentina for their antimicrobial activity. Letters in Applied Microbiology 32: 293-297.

Stepanovic, S, N Antic, I Dakic and M Svabic-vlahovic (2003). In vitro antimicrobial activity of propilis and antimicrobial drugs. Microbiol. Res.,158: 353-357.

Sundaram, S, Priyanka, D and Shali, P (2011). In vitro evaluation of antibacterial activities of crude extracts of Withania somnifera (Ashwagandha) to bacterial pathogens. Asian J. Biotechnol., 3: 194-199.

Tadeg, H, Mohammed, E, Asres, K and Gebre-Mariam, T (2005). Antimicrobial activities of some selected traditional Ethiopian medicinal plants used in the treatment of skin disorders. $J$ Ethnopharmacol. 100:168175.

Tedila .H and Assefa. A (2019). In vitro antibacterial activity of Rumex nervosus and Clematis simensis plants against some bacterial human pathogens. African J. of Microbiology Research: 13(1), pp. 14-22

Teferi, G (2003) .The use of medicinal plants in self-care in rural Ethiopia. J Ethnopharmacol ; 87:155-161. 